\section{Research Article}

(C) 2020 Edinyang et.al.. This is an open access article licensed under the Creative Commons Attribution-NonCommercial 4.o International License (https://creativecommons.org/licenses/by-nc/4.o/)

\title{
Almajiri System of Education and the Emergence of Religious Extremists in Nigeria
}

\author{
Sunday David Edinyang \\ Maxwell Richard Bassey \\ Doris Emmanuel Ushie
}

Department of Social Science Education, Faculty of Education, University of Calabar, PMB 1115, Calabar, Nigeria

Doi: 10.36941/jesr-2020-0030

Abstract

This paper describes Almajiri system of education and the emergence of religious extremists in Nigeria. Almajiri system of education being a traditional and non-formal system of education which derived its curriculum from the Holy Qu'ran and subjects its learners or pupils to roam about the streets begging for alms, food, and render menial labour to the teachers known as Mallams as a means of survival, is found majorly in the northern parts of Nigeria which later spread to other parts of the country and the world with devastating effects to the country's security apparatus as well as our cooperate existence as one indivisible entity. Consequently, these innocent children with little or no parental backgrounds are left to their fate constituting child labour, child abuse, child neglect, street hawking and other social vices while others join bad groups in carrying out crimes such as kidnapping, armed robbery, suicide bombings etc. This negates the contribution of education to nation building. The conceptual clarifications, historical perspectives, some factors affecting Almajiri system of education as well as suggestions and recommendations were extensively outlined.

Keywords: Almajiri System; Education; Religious Extremists; Child labour; Child Abuse; Child Neglect

\section{Introduction}

The issue of Almajiri system of education in Nigeria has attracted global attention. This is because of the current trends of insecurity, terrorism, child abuse, child labour, child neglect, kidnapping, electoral violence and malpractices, incessant killings and bombings and other social vices are at increasing rates in Nigeria. This is caused by the constant declining state of education and its role in child development and nation building in tandem with its national goals as contained in National Policy on Education (NPE,2004) in making Nigeria: A free and democratic society, A just and egalitarian society, A united, strong and self-reliant nation, A great and dynamic economy, and A land of bright future and opportunities for all (FRN,2004:7) while Nigeria's Philosophy of Education (Educational goals) are: (i) The inculcation of right type of value and attitudes for survival of the Nigerian society (ii) The inculcation of national consciousness and unity (iii) The training of the mind in the understanding of the world around, and (iv) The acquisition of appropriate skills, abilities and 
the individual to live and contribute positively to the development of his society which are all in line with the overall goals and objectives of social studies education in Nigeria.

Despite all the carefully selected goals, the state of education in Nigeria; be it traditional, religious, formal, non-formal or informal system of education, continues to be a national discourse at all levels. Consequently, the declining state of education with increasing negative impacts on the nation's moral, civic, cultural and economic aspects which has affected the collective existence and national development as one indivisible entity. However, Fafunwa (1974) listed the following goals of traditional African education in Nigeria:

a) To develop the child's latent physical skills

b) To develop character

c) To inculcate in the child respect for elders and those in position of authority

d) To develop intellectual skills

e) To acquire specific vocational training and to develop a healthy attitude towards honest labour

f) To develop sense of belonging and to participate actively in family and community affairs

g) To understand and appreciate and promote the cultural heritage of the community at large.

In view of all the above educational goals which are yet to be attained in the Nigerian context to contribute meaningfully to national development, Almajiri system of education as a traditional and non-formal education remains a nightmare to the country's cooperate existence irrespective of our religious and cultural differences and backgrounds.

\section{The Conceptual Clarifications of Almajiri System of Education in Nigeria}

Etymologically, the term "Almajiri" is derived from Arabic word "Al-muhajirun" which is being translated as "Migration" (emigrant or immigrant). It is traditional or non-formal system of education where a learner or pupil seeking Islamic knowledge migrates from his hometown to a popular teacher (Mallam). It is found majorly in the Northern part of Nigeria. (Guardian Newspaper May 29, 2019).In Hausa land, Almajiri could take a form of:

(a) A child who engage in some form of labour to earn a living (Yushau et al., 2013).

(b) Any person irrespective of the gender who begs for assistance on the streets or from house to house as a result of some deformity or disability.

(c) Children between the ages of 7-15 years who attend informal religious school who equally roam about with the purpose of getting assistance or alms.

Accordingly, "Almajiri" is an Arabic word (Almuhajirum) meaning "migrants". As referred to the time of prophet Muhammed (SAW) when the people of Mecca migrated to Medina. It is a traditional method of acquiring Islamic knowledge by memorizing the Glorious Quran. Among the Fulani/ Hausas, young boys between the ages of seven to fifteen ( $7-15$ years) are sent out by their parents or guardians to other towns, cities, or villages, for Qur'anic education under the knowledgeable Islamic teacher or scholar called Mallam. Bamback (2003) categorises Almajirai (plural of Almajiri) into 3 classes: "Gardi - (adult), Titibiri - (Adolescent) andKolo - (Infant)".

The Gardi (adult) engages in intense labour or services for financial or material rewards while the Titibiri (adolescent) and Kolo (infant) beg for food/alms. Almajiri is an educational activity though which the Almajiri (learners of traditional Islamic knowledge), get involved during the process of acquiring Quranic and Islamic education. It is an educational system that is basically religious and Islamic. As noted by Alkali (2001), Almajiri is a semi-formal education system relying solely on Quranic education, in which children, mostly boys are sent by their parents to take up residence with Islamic Mallams, for instruction in the Quranic and other Islamic texts. It also refers to the traditional inculcation of children into adulthood (i.e., learning how to fend for themselves) usually under the tutelage of a Mallam. More so, as a means of compensation for knowledge gain and for their wellbeing, the students could serve in their teachers' farm or beg for alms.

A study on "Begging among Almajiri Quranic boarding school children of Almajiri system of 
education in Sokoto Metropolis" by Ayuba (2009) aver that Almajiri practices are religiously legalized since the prophet (SAW) was reported to have advised Muslim to travel in search of knowledge. In Hadith, it is said that "whoever is able to set out seeking will be walking on the path of God until his return and whoever dies will be seen as a Martyr". This connotes why Islamic scholars and their students migrate or travel to different parts of the world in search of knowledge. However, the idea of begging was never the original plan of the Almajiri movement, as begging was discouraged by the Islamic prophet that brought Qur'anic and knowledge of Islam. The prophet noted that it is better for believers to fetch firewood for sell (work for pay) than to beg. As observed in Ibrahim (2010), Islam encourages knowledge seeking but does not in any way promote alms begging or allowing children to wander on empty stomach under the guise of attaining Qur'anic education.

The idea of Almajiri education particularly in the northern part of Nigeria, begin as a movement to enquire Qur'anic knowledge (Muhammed, 2010), with no laid down channel or procedure for admission (entry) except the unconventional way of handing over wards to the supposed instructor known as Mallam. It is the place of the instructor (Mallam) to indoctrinate the ward to the Islamic teachings and religious way of life. This was a rewarding experience for highly educated and successful "sheikhs" and Mulks holding positions of judges and teachers could mould the minds of the young teaching on how to become righteous and exemplary in their future lives.

According to Wikipedia, the term "Almajiri" is derived from an Arabic word "al-muhajirun", meaning a person who lives his home in search of Islamic knowledge. Parents take advantage of this to give birth to children they cannot carter for and eventually go to mosques and drop them there at the ages of 2 years. It is observe that majority of these children are dropped in the school at night and are transported to other parts of the world in the night which make these children difficult to trace their home background but choose to embrace whatever life offer to them by begging or do menial labour just to make ends meet.

It is worthy to note that the various scholars and authors did not take into accounts that the Almajirai (learners) or children did not come into the world by themselves but have parents who saw Almajiri as a dumping ground to help train or take care of children without considering the responsibilities of the family, or home background in the socialization process of the child as well as the learning outcome. As a system of education, its curriculum derived from the Qur'an subjecting learners to street begging, making learners to travel to others parts of the world in search of knowledge, doing manual labour in return to the services of the teachers are against the national goals of education and its role to nation-building and development but rather slavery, orphanage, total neglect, child labour, child abuse, which make them vulnerable to the societal crimes. The products of Almajiri are mobile tailors, shoe shiners/makers, herdsmen, barrow ushers and other street hawkers.

Report from Legit, August (2019) has it that the Governor of Kano State, Governor Ganduje has alleged that $90 \%$ of the Almajiri roaming the streets of Kano are majorly foreigners out of the total of the Almajiri in the state. In an attempt to stem the ugly situation surrounding this system of education, the Governor, Ganduje has introduced compulsory free education, "a policy that will an end to the excessive Almajiri system, 'we all believe that education is one of the major routes to economic prosperity and a corridor to scientific and technological advancement. It is at the same time as largely regarded and enunciated, a veritable tool to combat unemployment". He called on educational experts and professionals who specialize in basic education, some in science and technical education, and some in assessment and quality control in education, some in examination management while some would come from Almajiri system of education (Legit, 2019).

The above report is however a good attempt to ending religious extremists and other social vices in Nigeria, but fails to address the issue from the root, that is the home and family background of this children and the mobile nature of the system as well as using it as a tool for political violence, rigging of elections and destabilization of political opponents by empowering the Almajiris with dangerous weapons. Almajiri system of education is therefore defined as a migrative, orphanage and slavery system of education where learners at there are ages of 2 are dumped at mosques by poor 
parents, taught only Qur'anic knowledge through street begging, hawking and menial jobs for their teachers (Mallams). The devastating consequences of this system result to child abuse, child labour, neglect and vulnerable to social vices.

\section{Historical Development of Almajiri System of Education}

There are 2 versions on the historical development of Almajiri system of education in Nigeria:

- The Bebeji version and

- The Medina version

\subsection{Bebeji version}

The history of Almajiri could be traced to the advent of Alhassan in $18^{\text {th }}$ century. Alhassan was born in 1877 to the family of Addullahi and Amarya in Bebeji, Kano Emirate. Addullahi his father died when he was 8 years and Amarya his mother left him to a slave girl Tata to Accra in Ghana. Tata sent young Alhassan to Almajiri School in Bebeji, Kano State to learn from a Tijaniyya Mallam. At 17 Alhassan travelled to Accra, Ghana to see his mother. Thereafter, his mother took him to another Mallam. He later returned back to Bebeji to his foster mother Tata. He was taught thrift and hard work from Mallam. This knowledge helps him to work through trade routes that opened up several business opportunities during the British imperialism. Alhassan by 1906, was already demonstrating his power and bravery learnt for merchandise between Accra, Sekondi and Lagos. This made him the wealthiest man in West Africa, prior to his death; Alhassan Dantata was the great grandfather of Aliko Dangote and had been an Almajiri.

The Tsangaya system prevailed in Kanem-Borno Empire before British colonization in Nigeria. At that times, Tsangaya was established as an organized and comprehensive education system for learning of Islamic values and jurisprudence, principles, and theology as a school curriculum modelled after Madrasahs in Muslim societies. Tsangaya as a system was largely funded by the state.Traditionally, Islam encouraged charity so the community readily supported these Almajirai (learners). In return, the Almajiri gave back to the society through manual labour.

There was a curriculum modification by the DanFodio Jihad movement, which leads to the establishment of inspectorate of Qur'anic literacy (I Q L), with which theMallams (inspectors) reports directly to the Emir of the province concerning all matters relating to the school(s).At that time, the Almajiri schools were located within their immediate environment and therefore, pupils do not need to board but rather lived with their parents/guardians for moral upbringing. Learners were at liberty to choose and acquire skills in their Islamic curriculum which were involved in Agriculture, such as fishing and farming and other trades such as Masonry (such as stone, bricks, tiles etc). Dry Masonry which is applied to structures made without mortar. It is the craft institution or mysteries of free mason. They were the Masochist (someone who enjoys pains or who derives pleasure from harming oneself or being harmed by others). Others who were farmers formed the fame of Groundnut pyramids.

After colonization, the Almajiri students were recruited by the British as miners in Jos, Plateau State. The British also recruited teachers, judges, and clerks who provide the colonial administration with the needed manpower. The Almajiri schools provided the first set of colonial staff in the Northern part of Nigeria. The advent of the British rule lead to the capture of Emir Aliyu, of Kano and the death of Muhammadu Attahiru of Sokoto and many others. The Emir lost control of their indigenous system of education (Almajiri) and forcefully accepted the roles as vessels to the British. The British rule obliterated the state funding of Tsangaya curriculum, arguing that they were religious schools and introduced western education which the Almajiri saw it as "Karatun Boko" and was funded instead. The lost of support to Almajiri system lead to its collapse. Thus, since there was no financial support to the Almajiri educational system, the pupils and their Mallams resorted to street begging for survival. More so, resentment and hostility by the natives worsen in that the belief 
that Western education and the advent of Christianity brought by the Europeans would displace their Islamic identity. With this in mind, the Mallams more often send their students (almajirai) who refused to embrace Western-education out to beg to make ends meet since the Almajiri system, funding by state was completely abolished by the British officials or administrators. Some of the Mallams began to impose "Kudin sati" (a form of weekly levy, fee or target) of returns to be met by each of learners; propelling them that it is better to beg than to steal. The students in their turn swam into the society with no bearing. This was the genesis of the predicament of the Almajiri system of education. Source (Guardian Newspaper May 29, 2019).

The above report however did not take into account other family variables such as home environment, parental involvement, parenting style, socioeconomic status of the parents, family size or number of children, poverty, parents workload and unemployment single parenting and death of parents and other family variables which could influence the child's development in both moral values and intellectual performance instead of leaving the entire responsibility of child academic training on the Mallam that could lead to child abuse, street begging terrorism, kidnapping, armed robbery and other social vices which these almajirai are exposed to in order to make a living. It is however observed that the Almajiri system of education was mainly for children of parents from low class, poor homes, large family size parents, low socio-economic status etc. which saw Almajiri system as a dumping ground for their children. The Mallams in other hand saw the Almajiri system as a means for livelihood to enrich themselves from the proceeds of the learners begging which make the children vulnerable.

UNICEF (2014) reported that the number of Almajiri in Nigeria are 9.5 million or $72 \%$ of the country's $\mathbf{1 3 . 2}$ million out of school children. This report is a disaster to the country's future in peaceful existence as a people because these children are constantly being recruited into Islamic sects to carry out crimes in the society. Other estimates claimed that about 1.5 million of the country's out of school children, more of them which are found in the northern part of Nigeria where the crime rate of religious extremists are high. Clearly, the Tsangaya system of education in the Almajiri system is outdated and needs over haul with current standards of education irrespective of the religious background. The system is characterized with children who are constantly abandoned with no parental background with semi-literate Mallams as teachers who travel with these children to different cities mostly in the night through Lorries and other means.

The implications of the above historical facts means that the almajirai or learners take pleasure in pains as a learning process, can harm oneself or others as they struggle to carter for themselves and Mallams. The learning outcome of such graduates are herdmen, mobile tailoring 'obioma,', mobile shoe shiners, gatemen, barrow pushers etc while others who are unemployed can embrace whatever life offers just to make a living. The aversive effects is that some are lost through crimes, being indoctrinated and recruited into Islamic terrorist groups such as Boko Haram (Western education, forbidden or a taboo) banditry and violence in the streets while others are lost through hunger and diseases. Lack of parental care in raising number of children they cannot adequately carter for is one of the major setbacks to the Almajiri system of education with increasing population of abandoned children with the Mallams who are unable to travel and carter for them all.

\subsection{The Medina version}

This version holds that the Almajiri concept came as a result of prophet Muhammed's migration from Mecca to Medina (Yusha'u et al, 2013). This version contradicts other versions in that it forbids its learners from begging instead they preferred Almajiri to go to the bush and cut firewood and sell. It is however stated to have started in a town called Kanem-Borno in Nigeria which had majority of its rulers widely involved in Qur'anic literacy. More than 700 years later, the Sokoto caliphate was founded by the revolution based on the Qur'anic teachings. Sokoto and Borno caliphates started running the Almajiri system of education together with its curriculum derived from Islamic religion, during this pre-colonial era, learners used to stay with parents for proper morals and upbringing the 
schools were in close proximity with their immediate environment. The inspectorates of education were introduced who go around schools to report directly to the Emirs of the province. The Almajiri system were majorly funded by parents, Zakkah, Sadaggah, the community and sometimes through the farm output of the students.

In 1904 the British invaded the Northern parts of Nigeria who forcefully acquired territories and most Emirs were killed and others were deposed and others lost their territories and Almajiri system. The eradication of the Almajiri system of education by the British government during the colonial era with the total neglect to the Almajiri system and introduction of Western education gave birth to the establishment of "Boko" meaning Western education which was misunderstood to be Christian based education. The formation of the Islamic self-called Boko Haram implies "Western Education forbidden with a view to fighting for their religious beliefs. The British abolishes the Almajiri system with no financial support from the state government led to its collapse. The teachers (Mallams) and the students (almajirai) with no financial support resorted to begging and menial jobs (Yusha'u et al, 2013).

National Council for the Welfare of Destitute (NCND) reported that currently, an approximated 7 million Almajirai resides in Nigeria. However, the system is reported to lack basic facilities such as shelter, clothing, food provisions, teachers, and good basic amenities. Majority of these Almajiri do not graduate and are left with the option to beg and do menial jobs. The criticism of the above statement raised so many questions such as; who are the parents of these children? If colonialism led to its collapse, what happened to the system after Nigeria's independence in 1960 till date? Why the increase in out of school children population, what is Boko Haram one of the deadliest Islamic sect in the world more powerful in Nigerian than the security agencies? The numerous rhetorical questions form the basis for this paper.

\section{Religious Extremists in Nigeria}

This refers to Christian - Muslims contention in Nigeria traced back to the early $19^{\text {th }}$ century. In recent times, religious violence as dominated by the Boko Haram insurgency, which primary aimed at imposing Sharia on the entire nation (Nigeria), seeing Western education as Christian based and an abomination. Such violence as in the case of Tafawa Balewa in 1948, and the Igbo Massacre of 1966 in the North followed by a counter coup of the same year which lead to the death of many southerners. The tension between the Igbos and the local Muslims formed the genesis of Biafra session and the resulting to civil war. The amalgamation of Nigeria in 1914 by the British who did consider the indigenous traditional institutions of the various ethnic groups and the eradication of the Almajiri system of education are all matters of serious concern which calls for collective and concerted efforts of government and corporate bodies.

In view of all, the challenges of the Almajiri system, integration education became obligatory as a result of the predicament of the system. This refers to the amalgamation of the Almajiri educational system and the Western education which is liberal, giving learners the opportunity to choose between disciplines such as sciences, arts, business administration, social sciences etc and Qur'anic education which is purely religious. It is the worrisome situation of the dangers of increasing population in Almajiri system that the political elites saw it as a weapon for rigging of elections to their favour, making governance difficult for opponents through terrorism with the wandering Almajiri that lead to establishment of Almajiri integrated schools across all states in the Northern parts of Nigeria by the former President of Nigeria Dr. Goodluck E. Jonathan as one of the government's intervention programme to curtail the menace of street begging and other social vices but to meaningfully engage them in secular academics for a better future of the learners as well as the country as a whole. The aim of the amalgamation of the two educational systems was to provide educational opportunities for these categories of children who are exposed to child abuse, neglect, health hazards, hawking and other social vices. Many of the almajirai are orphans and vulnerable children to enable them acquire both the traditional Qur'anic education and basic western education 
in order to improve their living condition and empower both the Almajiri and the Mallams. This is to enable all states of the federation to achieve its Millennium Development Goals (MDGs) and to offer Education for All (EFA) (Yiesha'u et al, 2013).

\section{Factors/Problems of Almajiri System of Education}

According to Khalid (200o),the Almajiri educational system has been seriously criticised over the years for severely subjecting its students/client to a life of begging. Children between the ages of 5-10 years under the Almajiri system barely can fend for themselves or have any virtual or visible support or means of livelihood, rather they survive only at the mercy of the charity they receive from begging; showing the agonising and pitiable state of these children. This however shows that there are several factors contributing to the Almajiri problem over the years. Apart from wondering about and street begging, other factors include:

(a) Societal values and norms instigating the enrolment of children between 3-5 years in Qur'anic schools

(b) Poverty and parental ignorance as majority of these children came from peasant families.

(c) Government inconsistency and commitment on policy formulation and implementation.

(d) Distance between centre of learning and students' residence.

(e) Non-specific year of graduation in the traditional Qur'anic boarding schools which make the learners to lack the opportunities to access Western education. Other problems include:

- Unfriendly environment.

- Over crowdedness/overpopulation

- Inadequate instructional materials

- Insufficient teachers (Mallams) who are semi-literate.

- Inadequate commitment/support.

As explained by Muhammed (2010), people naturally develop disdain about the practices of the Almajiri educational system and therefore condemn and criticize the system on the following grounds:

- Inadequate provision of feeding which expose the learners to juvenile delinquencies.

- Over population.

- Lack of payment of salary

- Age factor

- Methods of discipline

Accordingly, Sule (2002) bewailed that the problems of the Almajiri system in the northern parts of Nigeria, manifests in various forms of social explosive such as:

- Mai-latsine crisis

- Yan-Daba phenomenon

- Area boys

- Yan-Daular Amaraya incidences

- Book Haram etc

Despite all the factors mention by various scholars, it is worthy to note that Almajiri system of education is seriously under contention due to the following characteristics:

(1) The system is not integrative with other disciplines but purely religious, traditional and Qur'anic education.

(2) The means of acquiring knowledge is derived mainly from the Quran.

(3) The system is migrative.

(4) The teachers (Mallams) are unemployed without any financial support except from the learners who are subjected to begging.

(5) It subjects learners to menial labour.

(6) The means of learning is through indoctrination.

(7) It is anti-Western education "Boko". 
(8) It is a wandering or vagabond education.

(9) It is iniquitous, sinful, obsolete and need a concerted effort.

(10)It is orphanage in nature to reform.

The problem is not with the system, but the process, the traditional Qur'anic schools still remained mostly one classroom outside the Mosque, private house or under the tree.The negative impact of the system are numerous ranging from child labour, child abuse, crimes, terrorism, banditry, herdsmen, Boko Haram and other social vices. As observed by Bako and Sule (1994), in the Northern part of Nigeria, the Qur'anic system preceded the Western education system but majority of the population in the north preferred the Qur'anic system to provide training for their children. An attempt to westernize the Almajiri system has been resisted as it has led to the formation of various Islamic movements such as Miyatti-Allah, Shiites, Boko Haram etc with powerful Mallams as leaders.

\section{Way Forward}

The following suggestions could be useful to reduction in crimes and religious conflicts in Nigeria;

(1) The establishment of integrated schools merging both Islamic and secular schools together.

(2) All Almajiri system should be made formal and updated to government schools.

(3) Compulsory employment and professional training for all Almajiri teachers (Mallams).

(4) Population policies that would regulate birth control in the number of children each couple should have to enable parents take up their responsibilities in giving their children quality education.

(5) Skill acquisition and generation employment opportunities for both learners, teachers parents and the entire citizenry.

(6) The curriculum of the Almajiri system should reflect the interest of the learners in line with the National Policy on Education (NPE) goals.

(7) Strong regulatory body by the government to checkmate the activities of Alhaji or politicians who see Almajiri system as a tool for winning or rigging elections for selfaggrandizement.

(8) The introduction of school feeding by the present president Muhammadu Buhari is in line with the philosophy of Almajiri system as a backbone to helping these vulnerable learners in Almajiri system of education.

(9) The recognize Almajiri system as formal education.

\section{Conclusion}

The Almajiri system of education which has attracted global attention due to its outdated curriculum in subjecting learners to begging and other menial jobs resulting to street hawking, child abuse, bombing and killing of innocent citizens due to its neglect by government and stakeholders needs urgent attention on it curriculum review and the need for integration and incorporation into a formal school system with professional training of teachers (Mallams) and gainfully employed and engaging the learners in meaningful entrepreneurial skill development aimed at achieving the National goals on education for the betterment of all as well as tolerance and respect for other religious groups in Nigeria.

\section{Recommendations}

The following recommendations if followed and implemented may enhance the Almajiri system as well peaceful co-existence.

(1) Its goals should not be different from the national goals of education and so there is need for curriculum update to the current school standards.

(2) The Qur'anic knowledge should be combined with other disciplines to bring about positive 
change of attitudes for national development and self-reliance.

(3) School feeding programme should be sustained particularly in the Northern part of the country.

(4) Parental role should not be neglected and learners should be allowed to return home after school activities.

(5) All Mallams who refused to subscribe to the federal government's policies on education should run such schools as private learning institutions like every other private schools with current standards.

(6) Immigration policies should be effectively checkmate.

(7) The home/family should form the basis for the system.

\section{References}

Abdullmalik, I. (2008). Islamic Education an instrument for Realization of Nigeria's Vision 2020; Fartaru, J. MultiDisciplinary Study, 3, 257-261.

Abuh, Adamu (2015). "Nigeria. Fresh Onslaught AgainstAlmajiri Scourge via All Africa.

Amnesty International Report on Saudi Arabia (2009).Archieved from January, 15, 2010.

Amnesty International Report on Saudi Arabia (2009).Archived March 22 ${ }^{\text {nd }}$, 2011, at Wayback Machine.

Ayuba, S. D. U. (2009). "Begging Among Almajiri Quranic Boarding School Children of Almajiri System of Education in SokotoMethropolis. Unpublished M.Ed. Dissertion, Department of Education UDU, Sokoto.

Bambale, K. J. (2003). "The Need for Reform of Almajiri system to Education for attainment of the Nigeria Vision 2020".Farfaru Journal of Multi-Disciplinary Studies. Special Conference Edition, 3, 519-524.

Guardian Newspaper May 29, 2019.

Hamza, B. A. (2009).Problems and prospects of Almajiri System in Nigeria.J. Art. Soc, 1(2) 142-157. COE.

Hassan, I. (2010). "From Streets to Madrasse.The Transformation of Al-majiri.Retrieved August, 16, 2011. 12.35.

Ibrahim, A. A. (2010). The issue of integration Qur'anic and Western types of school: Issues and implications. Islamic University Quarterly Academic Journal; No. 1 Vol. International Colleges of Islamic Science, Berut, Lebnon.

Ja'afar, A. A. (2008). The Almajiri System of Education and The Vision 2020". Farfaru Journal of Multi-Disciplinary Studies.

Junaid, M. I., Dukku, M. G., Umar, A. (2005). Integrating Qur'anic schools into UBE programme: A survey of six Northern States. A joint UBE/UNESCO project report.

Khalid, (2002)."Nigeria's Educational Crisis: The Almajiri system and social realities in Islamic Culture, vol. LXXV, no. 3 July.

Muhammed, I. S. (2010).“Towards Reforming Al-majiriQur'anic School System of Education in Nigeria. Seminar paper. NAPS-RELGS, FCT College of Education Zuba, Abuja.

Okonkwo, O. S. (2017). The Almajiri System and Violent Extremist in Northern Nigeria.Finding the Nexus.

Shittu, A. B. Olaofe, M. A. (2015). Situation of the Almajiri system of Education in contemporary Nigeria.Matters Arising.Ilorin Journal of Religious Studies (IJOURELSo Vol, no 2 pages 37 - 46.

ZEISS Industrial Methodology Homepage www.cmm.com. 